研

究

\title{
新しい射出成形法－QSPによる機械構造用焼結低合金鋼の諸特性
}

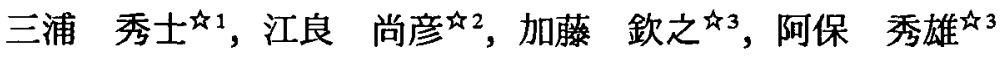

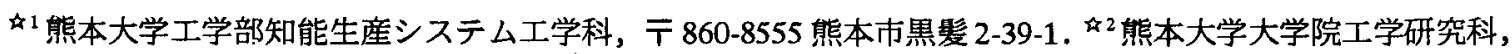

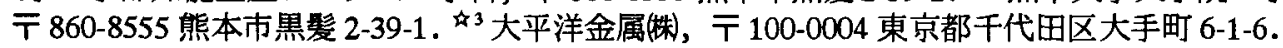

\section{Properties of Machine Structural Sintered Low Alloy Steels by New Injection Molding Process - Quick Set Process}

\author{
Hideshi Miura ${ }^{\text {4 } 1}$, Naohiko Era ${ }^{\text {क } 2}$, Yoshiyuki Kato ${ }^{\text {t3 } 3}$ and Hideo Abo \\ $4{ }^{2}$ Dept. Mech. Eng. \& Materials Sci., Kumamoto University, 2-39-1 Kurokami, Kumamoto 860-8555. \\ ${ }^{4}$ ' Graduate School, Kumamoto University, 2-39-1 Kurokami, Kumamoto 860-8555. \\ (3) Pacific Metals Co., Ltd., 6-1-6 Otemachi Chiyoda-ku, Tokyo 100-0004.
}

Received July 28,1999

\begin{abstract}
SYNOPSIS
Metal Injection Molding (MIM) process is a manufacturing route for mass-production of high density, highperformance, and near net-shaped metal components. However, MIM processes have been still limited in the size of the components. A Quickset process (QSP) has been invented as one of solutions for the issue. A feature of QSP is the manufacturing of large size parts that can not be made by the usual MIM processes based on a thermoplastic binder system. Although assessment of the properties such as strength are important to design the reliable machine structural parts, there are few reports about the properties of the materials produced by QSP at the present time.

In this study, the behavior of properties (relative density, hardness, tensile and fatigue strength) for machine structural low alloy steels produced by QSP have been investigated. The tensile strength of QSP alloy steels were equivalent to those of MIM alloy steels. However the fatigue strength of QSP alloy steel was relatively low, because of the coarse pores due to the segregation of binder occurred at water freeze injection molding step.
\end{abstract}

\section{KEY WORDS}

quickset process, water freeze injection molding, machine structural low alloy steel, mechanical properties

\section{1 緒言}

金属粉末射出成形(MIM) 法によれば，焼結性が良好な微粉 末とバインダを加熱混鍊することで流動性を付与し，三次元 的に複雑な形状の高密度焼結体を作製することが可能である. ただ，本法では，射出成形後，すなわち焼結前までにバイン ダを除去する脱バインダ工程を必要とし，その際バインダの 熱分解ガスの排出経路を確保する必要性があることから大型, あるいは肉厚の部品作製は困難であり，小型の精密部品に限 定されているのが現状である。 そこで，この種の欠点を補う べく開発されたものにクイックセットプロセス (QSP) がある か，それによればバインダの主成分が水であり，水分の昇華 を基本とした脱バインダを行うため，セラミックス材料を中 心に䄪 $1000 \mathrm{~g}$ 程度の大型複雑形状の高密度焼結体を作製する ことが可能であると報告”されている，しかし，QSP を金属 粉末に適用した例 ${ }^{2}$ は極めて少なく，今後の対象鋼種の拡大 という意味では種々の材料についての調査が必要である.
本研究では，量産性という観点から機械構造用低合金鋼を 対象鋼種とし，本鋼種に及ぼすQSPのプロセス因子の影響お よびQSP材の各種特性について調査し, 従来の射出成形法に よる MIM材との比較検討も行った.

\section{2 実験方法}

QSP 用の原料粉末には，Table1, 2 に示すような粉末特性が 異なる 2 種類 $(\mathrm{H}, \mathrm{L})$ の水アトマイス SCM415 合金鋼粉末を用 いた.バインダには水を主成分とするバインダ(保形性のため の若干の有機添加剤混入)を使用し,まず金属粉末とバインダ をそれぞれ体積比 52:48で調合し，常温で混練した後，凍結射 出成形機により凍結成形体を作製した．成形体は水の三重点 以下の温度ならびに圧力で，水分のみを直接昇華させるため の真空乾燥を施した．続いて窒素雰囲気中，加熱脱脂により 有機添加剂を揮散させ，焼結は真空雾囲気中 $1623 \mathrm{~K}$ の温度で 種々の時間(0.06〜10.8ks) 行った. 得られた焼結試料 (丸棒状: 
Table 1 Chemical compositions and characteristics of powders used in this study.

\begin{tabular}{lccccccc}
\hline \multicolumn{1}{c}{ (mass\%) } & Cr & Mn & Mo & C & O & $\begin{array}{c}\text { Mean Particle } \\
\text { size }(\mu \mathrm{m})\end{array}$ & $\begin{array}{c}\text { Tap density } \\
\left(\mathrm{Mg} / \mathrm{m}^{3}\right)\end{array}$ \\
\hline Powder H & 1.00 & 0.73 & 0.22 & 0.31 & 0.42 & 10.0 & 4.78 \\
\hline Powder L & 0.98 & 0.60 & 0.23 & 0.17 & 0.48 & 7.84 & 4.27 \\
\hline
\end{tabular}

Table 2 Particle size distributions of powders used in this study.

\begin{tabular}{lcccc}
\hline Particle size & $+30 \mu \mathrm{m}$ & $30 \sim 20 \mu \mathrm{m}$ & $20 \sim 10 \mu \mathrm{m}$ & $-10 \mu \mathrm{m}$ \\
\hline Powder H (mass\%) & 4.2 & 13.1 & 33.1 & 49.6 \\
\hline Powder L (mass\%) & 0.1 & 3.2 & 30.6 & 66.1 \\
\hline
\end{tabular}

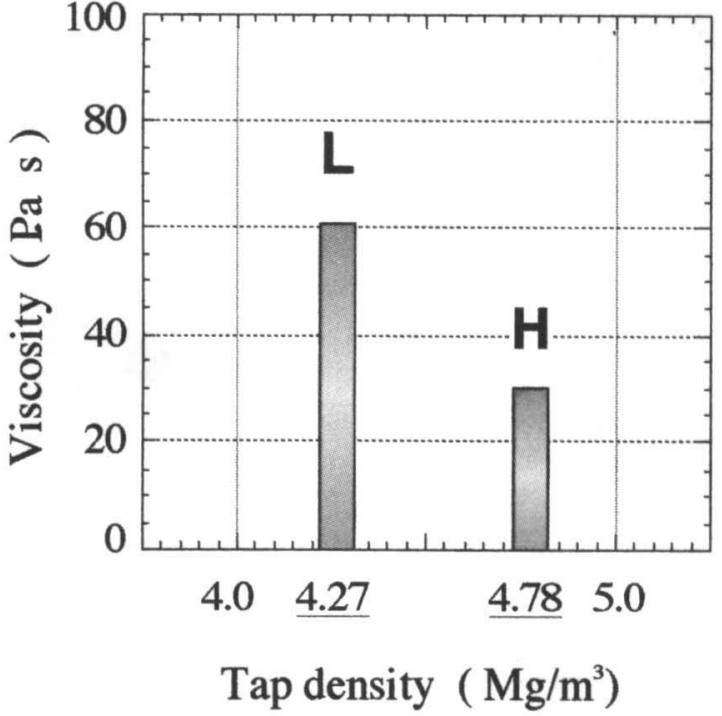

Fig.1 Tap density and viscosity of slurry for powder $\mathrm{L}$ and $\mathrm{H}$.

$13.5 \phi \times 113 \mathrm{~mm})$ については, 引張および疲労試験片に加工後， 熱処理あるいは浸炭処理を施して各種試験および組織観察に 供した.

MIM材については, パラフィンワックス $69 \mathrm{mass} \%$, ポリプ ロピレン 20mass\%，カルナウバワックス 10 mass\%およびステ アリン酸1mass\%からなるワックス系バインダを使用し, L粉 末とバインダとを体積比 $60: 40$ で調合し, 423Kで 3.6ks 加熱混 練したのち, 横型スクリュー式射出成形機により回転曲げ疲 労試験片を作製した. 得られた成形体は,ヘプタン気相中に 353Kで18ks保持して主にワックス成分を抽出したのち, 残り のバインダ成分を $30 \% \mathrm{H}_{2} / \mathrm{N}_{2}$ 混合雾囲気中 ( $\left.873 \mathrm{~K}\right)$ で加熱揮散

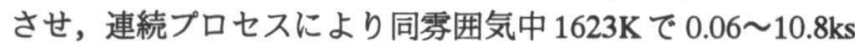
の焼結を施した. 得られた焼結体には QSP材と同様の処理を

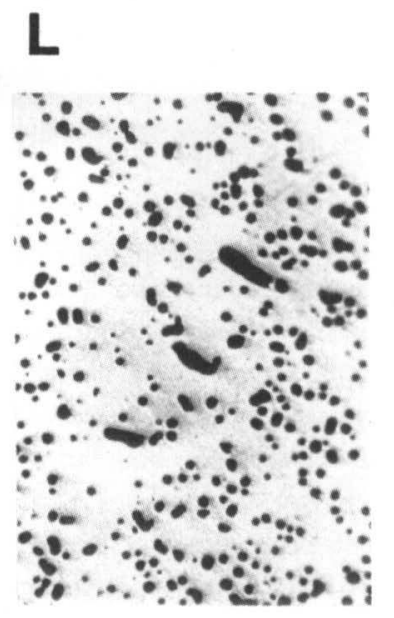

H

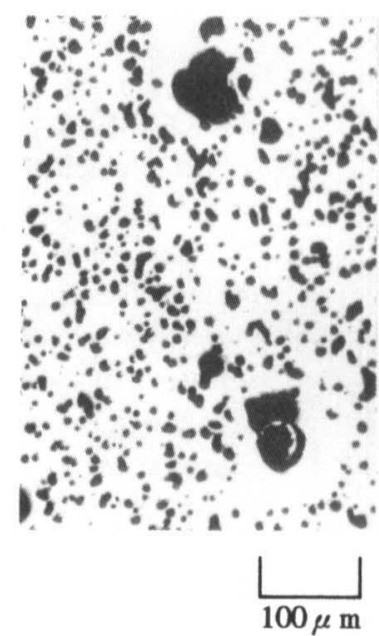

Fig.2 Microstructures of sintered QSP compacts using powder L and $\mathrm{H}$.

施し, 各種試験結果はQSP材との比較検討に用いた。なお, 機 械的性質の比較を行う際に重要となる炭素量の制御に関して は，それそれのプロセスに適した方法により，QSP 材では黒 鉛添加, MIM 材では雾囲気制御により両焼結体の炭素量を 0.2 mass\% に正確に制御し, 各種試験に供した.

\section{3 実験結果および考察}

\section{1 粉末特性の影響}

まず，QSP 材の作製に適当な粉末特性を把握するため, Table1 に示した 2 種類の粉末について検討した. 両者ともに 丸味を帯びた擬球状粉末であるが, 平均粒径が若干異なるた め, 例えば粒径が小さな粉末では混練物の流動性に影響を及 ぼすタップ密度は低くなっている(以後, タップ密度の高い粉 
末をH粉末, 低い粉末をL粉末と区別して表現する). Fig.1に 両粉末のタップ密度と混練物の粘性の関係を, またFig.2には 得られた焼結体の気孔組織を示す. タップ密度の高いH粉末 を使用した場合には，L粉末を使用した場合に比べ混練物の 粘性は低く, また焼結体中の気孔組織には粉末粒子間に形成 される気孔とは趣の異なるかなり大きな空隙が残存していた. 両粉末におけるこのような気孔組織の違いには混練物の粘性 が影響していると考えられたことから, 真空乾燥後の試料内 部についても組織観察を行った. Fig.3にその結果を示すが, $\mathrm{H}$ 粉末で作製された成形体中にはすでに粗大な空隙か残存 しており, L粉末の場合にも小さいながらも空隙が観察され た.このような空隙は焼結を施しても消失せず, 最終的には 両者の気孔組織に差異が生じたと考えられる. その場合, 混 練物の粘性が低いと,バインダと粉末の分離が生じ易くなり, バインダの偏析した部分が形成される. その偏析部は, 真空 乾燥工程で脱ガス化し, Fig.3に示したような空隙が真空乾燥 試料中に残存したものと考えられる.よって, QSP 用の混練 物に要求される粉末特性としては, 粉末とバインダが分離し やすいので, それを少しでも抑制するため粉末粒子間の摩擦 が大きな, すなわち夕ップ密度の低い粉末を用いることで粗 大な空隙の発生をある程度抑制できたと言えよう.

\section{2 相対密度の検討}

L粉末を用いた QSPおよびMIM 両焼結体の狫結保持時間に 対する相対密度を Fig.4に，また $10.8 \mathrm{ks}$ 焼結体の気孔組織を Fig.5 に示す. 焼結温度が $1623 \mathrm{~K}$ に達した時点 $(60 \mathrm{~s})$ では, 両 焼結体において約3\%の密度差が生じているが, QSP材におい
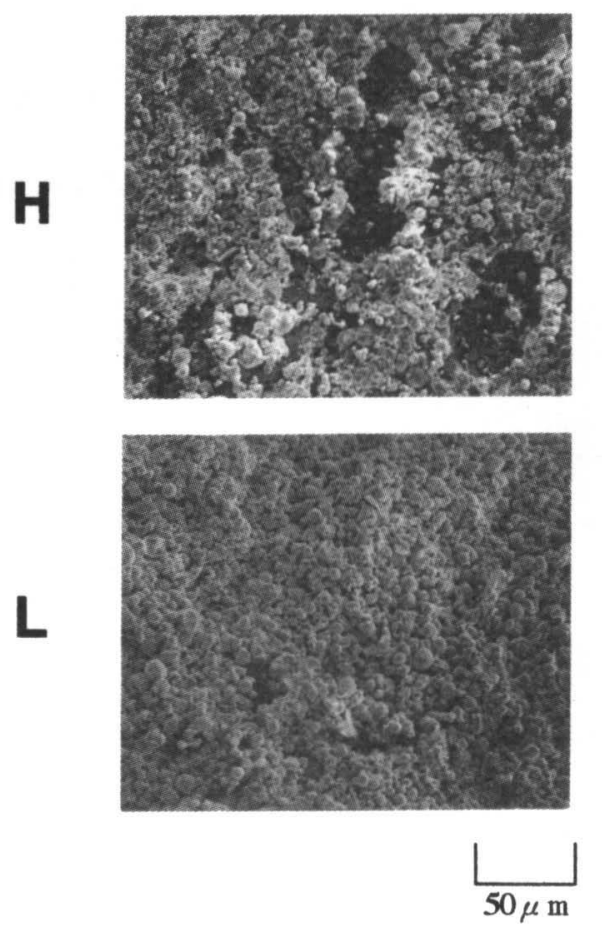

Fig.3 Microstructures of vacuum dried QSP compacts using powder $\mathrm{L}$ and $\mathrm{H}$.
てはMIM材に比べて混練物中の粉末割合か低かったため,こ のような密度差が生じたと考えられる. ただ保持時間が長く なれば, その密度差も小さくなり, 保持時間 10.8ksではほぼ 同程度の相対密度の焼結体が得られた。しかし, それらの気 孔組織においては若干様相が異なっており, MIM材では微細 な球状気孔が均一に分布しているのに対して，QSP材ではそ の大きさ，分布ともに均一性に欠けていた.

ところで QSP材の䋊密化の挙動に関しては, 酸化物の還元 作用が大きく寄与2していると考えられたことから, プロセ ス中の炭素, 酸素含有量の変化を調查してみた. Fig.6に結果

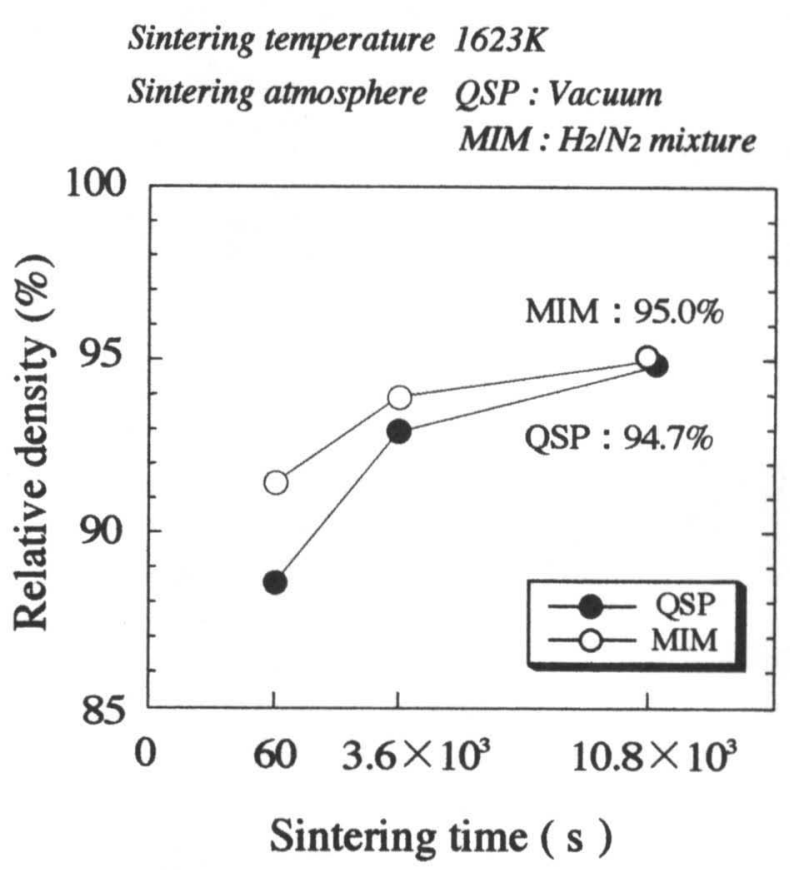

Fig.4 Relation between relative density and sintering time for QSP and MIM compacts.

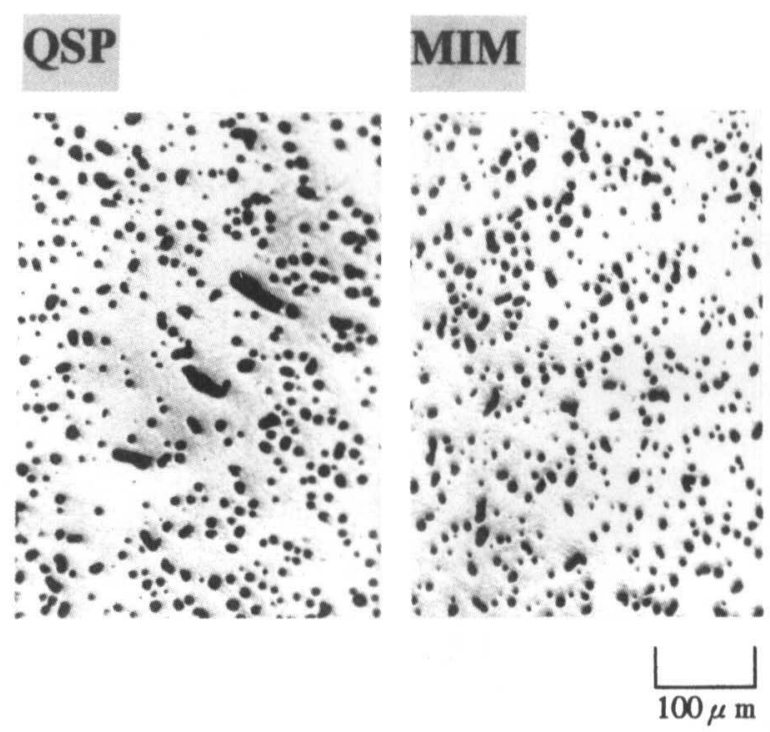

Fig.5 Microstructures of sintered QSP and MIM compacts. 
を示すが, 混練, 真空乾燥, 加熱脱脂の各試料中の炭素およ び酸素の含有量については, バインダ量と酸化の程度に応じ た結果を示しているものと思われる. 加熱脱脂から焼結にか けては炭素量の低下に比へてて酸素量の低下が著しい傾向を示 しているが, 焼結工程での雾囲気は真空であり, 真空雾囲気 中での酸化物の還元反応に良く対応していることから，加熱 脱脂後に適量の炭素, 酸素が存在したことで還元反応が促進 し，密度が上昇したと考えられる ${ }^{3)}$ 。なお QSP材と MIM 材に おいて, 最終的にほぼ同一の焼結密度が得られたことについ ては, 焼結後の酸素含有量に大差なかったことからも, QSP

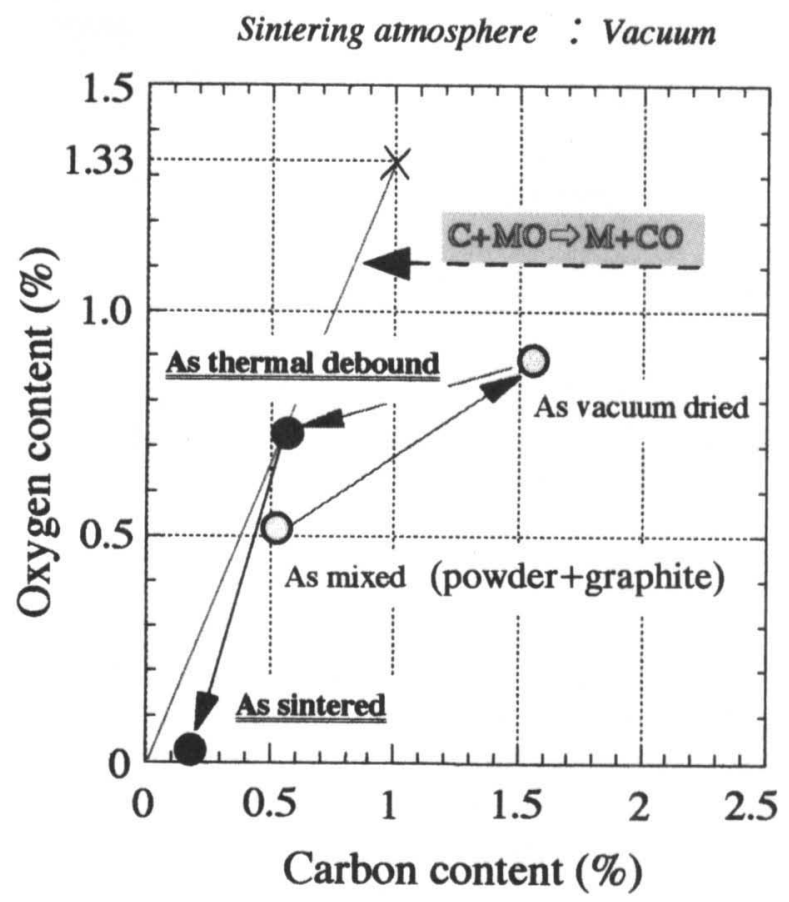

Fig.6 Change of carbon and oxygen contents of QSP compact.

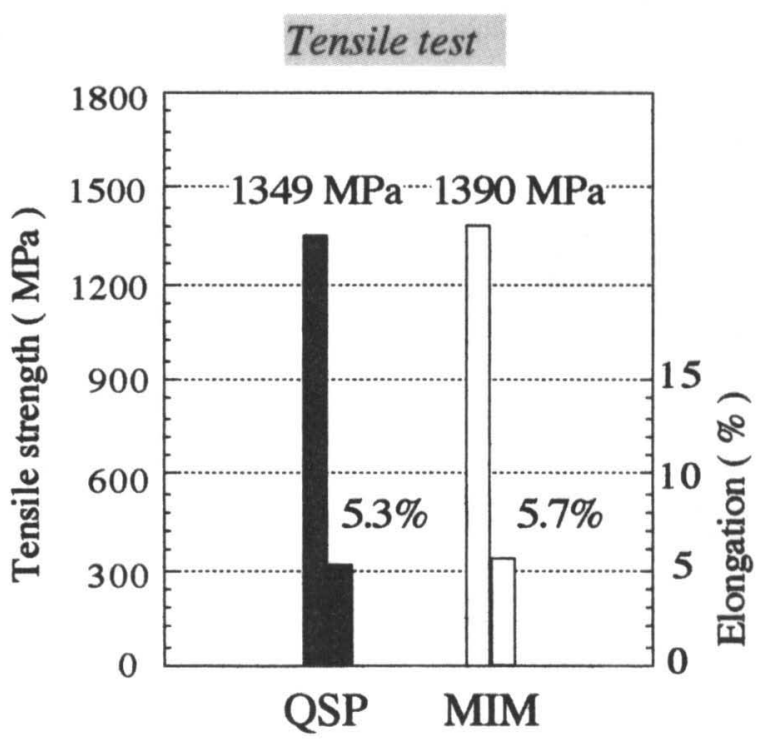

Fig.7 Tensile properties of QSP and MIM compacts.
での水バインダ使用による酸化はさほど問題にする必要はな いことを示唆しているものと思われる.

\section{3 機械的性質の検討}

QSP材とMIM材では同一焼結密度であっても気孔組織に差 異があることから，両プロセス材の機械的性質についても評 価を行った. 焼結体をアルゴン雾囲気中1173Kで1.8ksの溶体 化後油焼入れし，ついで $473 \mathrm{~K} て ゙ 3.6 \mathrm{ks}$ の焼もどしを施した試 料の機械試験結果を Fig.7, 8に示す. 引張および疲労強度とも に, 微細かつ独立球状の気孔が均一に分布した MIM材で若干 高い值が得られた。ところで，QSP材について疲労試験後の 破面を観察したところ, Fig.9に示すように表層部に粗大な気 孔が残存している試料もあり，このことは疲労き裂が発生し

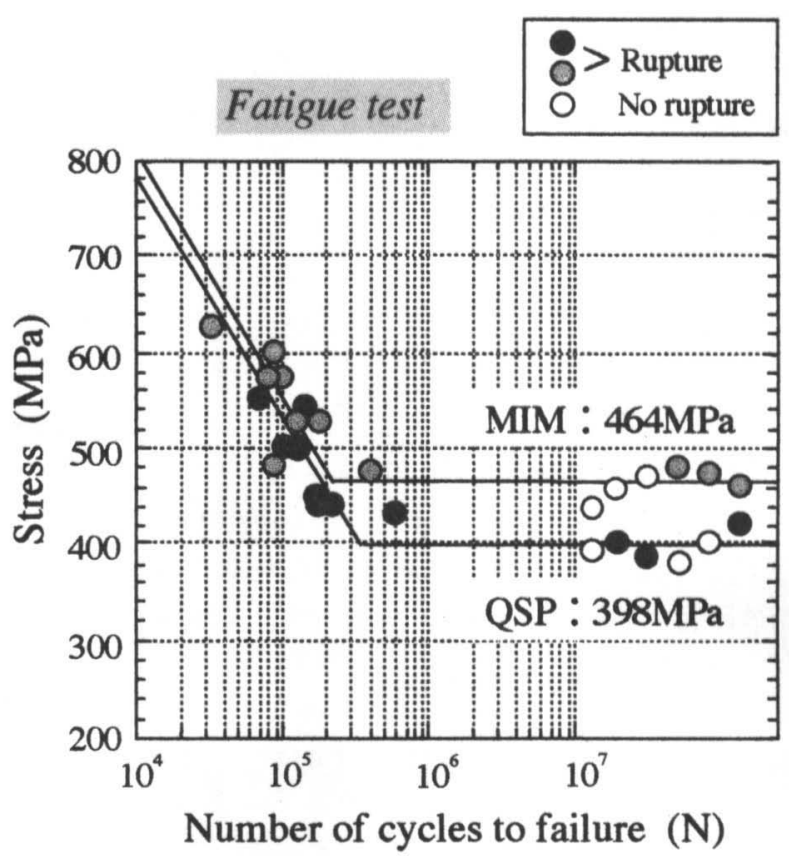

Fig.8 Fatigue properties of QSP and MIM compacts.

\section{QSP}

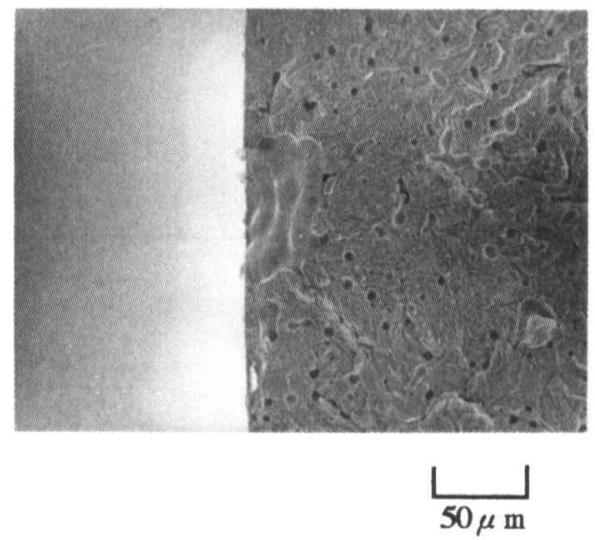

Fig.9 SEM image of fatigue fractured surface of QSP compact. 


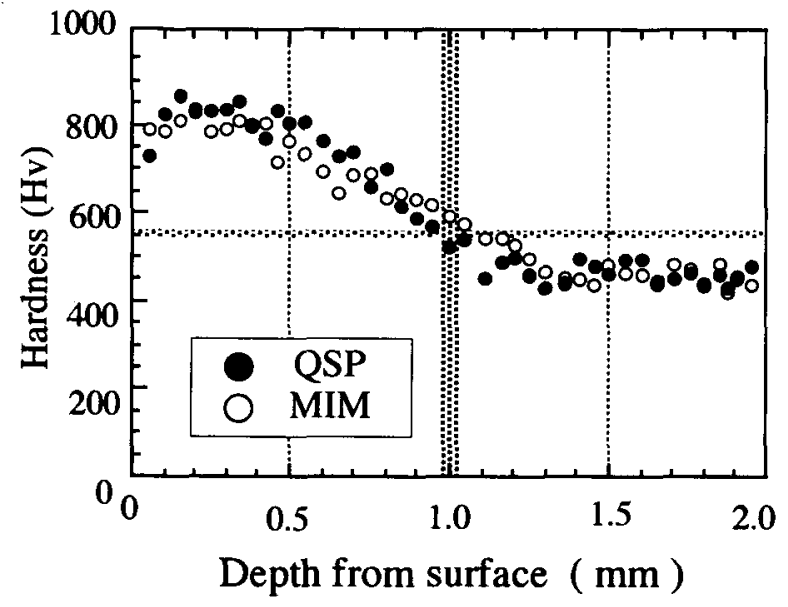

Fig.10 Hardness distribution from the surfaces of carburized and tempered QSP and MIM compacts.

やすい状態であることを意味していることから，特に疲労強 度には気孔組織の違いが大きく反映されたものと言える. 次 に，QSP材およびMIM材に浸炭熱処理を施した場合について も検討した. 固体浸炭法 (浸炭剂 (木炭: $60 \mathrm{mass} \%, \mathrm{BaCO}_{3}$ : 30 mass \%, $\mathrm{Na}_{2} \mathrm{CO}_{3}: 10$ mass\%), 漫炭温度: $1183 \mathrm{~K}$, 浸炭時間: $21.6 \mathrm{ks})$ により浸炭したのちアルゴン雲囲気中で一次焼入 $(1148 \mathrm{~K} \times 1.5 \mathrm{ks})$ および二次焼入 $(1098 \mathrm{~K} \times 1.2 \mathrm{ks})$ 後, 焼もどし $(473 \mathrm{~K} \times 3.6 \mathrm{ks})$ を施して得られた試料の表層部における硬度フ ロファイルを Fig.10に示す．再試料ともに類似の浸炭熱処理 特性を示しており，浸炭有効硬化層深さ (550Hv) はQSP, MIM 材ともに表層から $1 \mathrm{~mm}$ 程度と評価でき，溶製材と同様な漫炭 熱処理が可能であった. Fig.11に熱処理材ならびに浸炭熱処 理材の引張と疲労試験結果を示すが, 特に浸炭熱処理材の疲 労強度においても熱処理材と同様, QSP材の方がMIM材に比 ベて劣っていた。この点についてもやはり QSP材では不均一 な気孔組織が大きく影響したと言えるが，表面層を起点とし た破壤を抑制する目的で浸炭を施した効果は顕著に現れてお り，QSP材，MIM材ともに $250 \mathrm{MPa}$ 程度の向上が見られ，疲 労破壊に対する表面硬化はかなり有効であることがわかった。

\section{4 結 言}

QSPにより作製した機械構造用焼結低合金鋼の諸特性につ いて調查検討した結果，以下の結論が得られた.

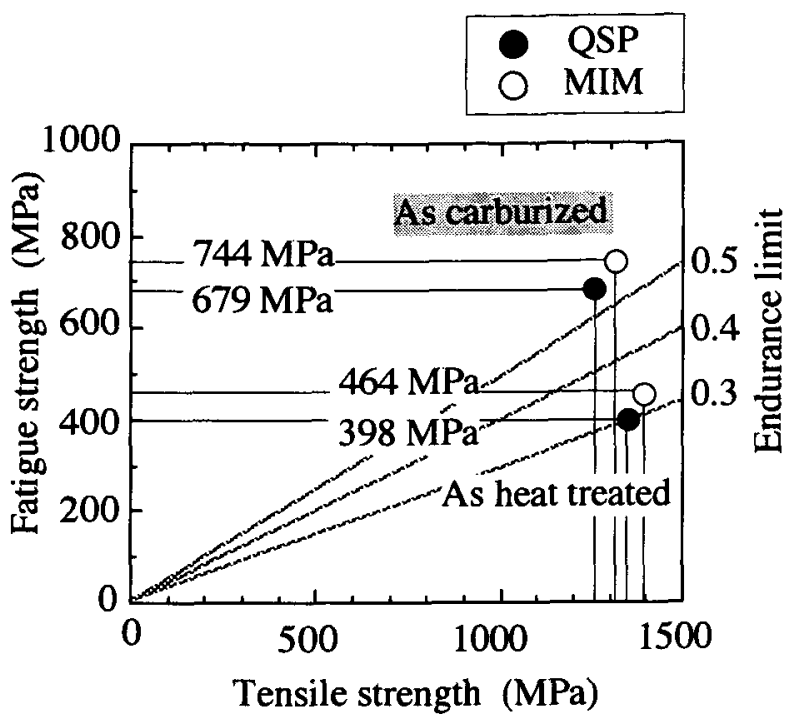

Fig.11 Relation between tensile and fatigue strength for QSP and MIM compacts.

（1）原料粉末特性ならびに湦練物の粘性の筧点から换討した結 果，QSPではタップ密度が若干低い粉末を使用すること で，相対密度約 95\%の焼結体を得ることができた．ただ， 同一焼結密度の MIM材と比較すると所々に粗大な気孔が 残存していた。

(2) QSPにおいては,水バインダ使用による酸化の焼結に及ぼ す影翌が照念されたが，真空雾囲気下でのCO生成反応を うまく利用することで還元でき，焼結による編密化は十分 に進行した.

(3) QSP 材の静的破壊強度は MIM材に匹敵する結果が得られ たが，動的破壊強度においては粗大気孔の残存により MIM 材に比べ劣っていた.

\section{文献}

1) C.Quichaud: "The quickset process", Proceedings of Powder Metallurgy 94 World Congress, EPMA, 2(1994)1101-1104.

2) 林, 木原, 林: "炭素粉添加によるカーボニル鉄微粉の…", 日本金属学会誌, 57(1993)289-295.

3) 杉山, 村田, 天野,和出，木村: "射出成形した SUS304Lス テンレス鋼の…",粉体および粉末冶金, 44(1997)416-421. 